\title{
WAYS OF DEVELOPMENT OF THE POTENTIAL OF STATE IN THE MARINE ECONOMIC COMPLEX: ECOLOGICAL AND ECONOMIC ASPECTS
}

\author{
Olena Borshchevska ${ }^{1}$, Eduard Kuznetsov ${ }^{2}$, Sergiy Stepanov ${ }^{3}$
}

\begin{abstract}
At present, issues of assessing the impact of economic activity on the environment as an integral part of the country's economic development are becoming more and more relevant. Environmental problems of the development of a marine economy complex may restrain the development of the economic potential of the state. Moreover, the dynamic development of the state's economy is possible only when economic entities adhere to the norms of an ecological nature. In this regard, the problem of assessing the impact on the environment, in particular, in the maritime complex in the projection of the economic component of development, as well as in this sense and the rational use of natural resources, is of paramount importance. The environmental tension is most often due to the placement of powerful chemical and petrochemical industries in the area of the maritime complex. In some areas, the level of environmental pollution is quite high due to the location of large facilities in the electric power industry (thermal and nuclear power plants). The economic component of the environmental impact assessment of the maritime complex is that one and the same natural resource is most often used by the economic entities of several countries. Therefore, the assessment of the impact on the environment and the achievement of a balanced distribution of ecological and economic benefits for the rational use of natural resources, especially in the maritime complex, are today of great relevance. The purpose of the article is to analyse the problems of ecological and economic orientation in the maritime complex and, on the basis of generalization of such problems, to provide recommendations on systematization of measures for the comprehensive rational development of economic relations, taking into account the features of the coastal zone and the marine economic complex. Methodology. Analytical market reviews, materials of periodicals, resources of the Internet are the informational and methodological basis of the investigation. To achieve the goal set, the following general scientific and special methods were used: economic and mathematical methods, structural-logical analysis, analogy, synthesis, comparison and integration, factor analysis. Result. The system of measures of an economic and legal nature, which should be taken into account for successful and rational use of the marine economic complex in economic activity, is substantiated. Problematic aspects and directions of their elimination are determined. The proposed model of the ecological and economic system of the maritime complex acquires a special significance in the context of the supranational task of developing measures for optimizing and rational use of natural resources on a global scale. The directions of the reform of the legal framework are considered. Practical value. The system of measures of economic and legal character and their individual types can be applied for optimization and rational use of marine (water) resources, taking into account the peculiarities of economic development and the state of the marine-economic complex in Ukraine and in other states. Value/originality. Most scientific works are devoted to the consideration of theoretical aspects of ecologicaleconomic systems, namely, the refinement of the essence of this instrument as a form of modern financial and economic dynamics. A part of the work is devoted to the consideration of the common features and national peculiarities of ecological and economic systems in individual countries and regions. The authors consider the issues of elaboration of measures for the optimization of economic activity, which combines the abovementioned aspects with the peculiarities of the formation of ecological-economic systems in the marine faring complex.
\end{abstract}

\footnotetext{
Corresponding author:

${ }^{1}$ Odessa National Maritime University, Ukraine.

E-mail: elennika@bigmir.net

ORCID: https://orcid.org/0000-0003-2549-429X

${ }^{2}$ Odessa I.I. Mechnikov National University, Ukraine.

E-mail: edkuznietsov@gmail.com

ORCID: https://orcid.org/0000-0001-7569-7533

${ }^{3}$ National University “Odessa Maritime Academy”, Ukraine.

E-mail: elit-@ukr.net

ORCID: http://orcid.org/0000-0001-6371-7672
} 
Vol. 4, No. 4, 2018

It is also important to take into account the impact of planned legislative reforms on the development of economic activity in the marine faring complex of Ukraine. The account of the peculiarities of the maritime complex in the framework of the national economy allowed developing directions for its further development.

Key words: ecological-economic system, marine economic complex, economic activity, rational use of resources, estimation of influence of economic activity on environment.

JEL Classification: Q22, 25, R19

\section{Introduction}

At the opening of the UN conference in Stockholm in 1972, its leader M. Strong spoke about the need for people to move from an economic concept to an ecological and economic system.

In recent years, the concept of "ecological and economic system" (further EES) scientists treated differently. For example, it is defined as a limited part of the technical sphere, in which natural, social, and production structures and processes are interconnected with flows of matter, energy, and information (Akimova and Khaskin, 2001). EES is flexible and, for each region, it is necessary to develop an individual specific nature management (Syromyatnikova, 2011). This should be accepted since people often neglect the balance of ecology and industry, pumping out natural resources, deforesting forests, flooding certain territories ("industrial regions"), because of which, at best, the ecological situation in them is in imbalance, and at worst - floods, earthquakes, technogenic catastrophes, etc. begin.

In the classical sense, the ecological and economic system is represented in the form of a biochemical cycle of natural resources that are extracted as a result of production activities and are directed to meet human needs. The next step is the recycling of the waste material or its disposal, which results in secondary resources that are sent for re-consumption (Figure 1).

Analysing the above interpretations of the ecological and economic system, it can be concluded that the stability of EES depends on the balance of humannature relations. The development of technical progress leads to an increase in the volume of consumption of natural resources, but their extraction and waste from their use cause irreparable harm to the environment. The development of production leads to a steady increase in the volume of consumption of resources and the expansion of their range. But, firstly, the resources are limited. Secondly, the use of almost every kind

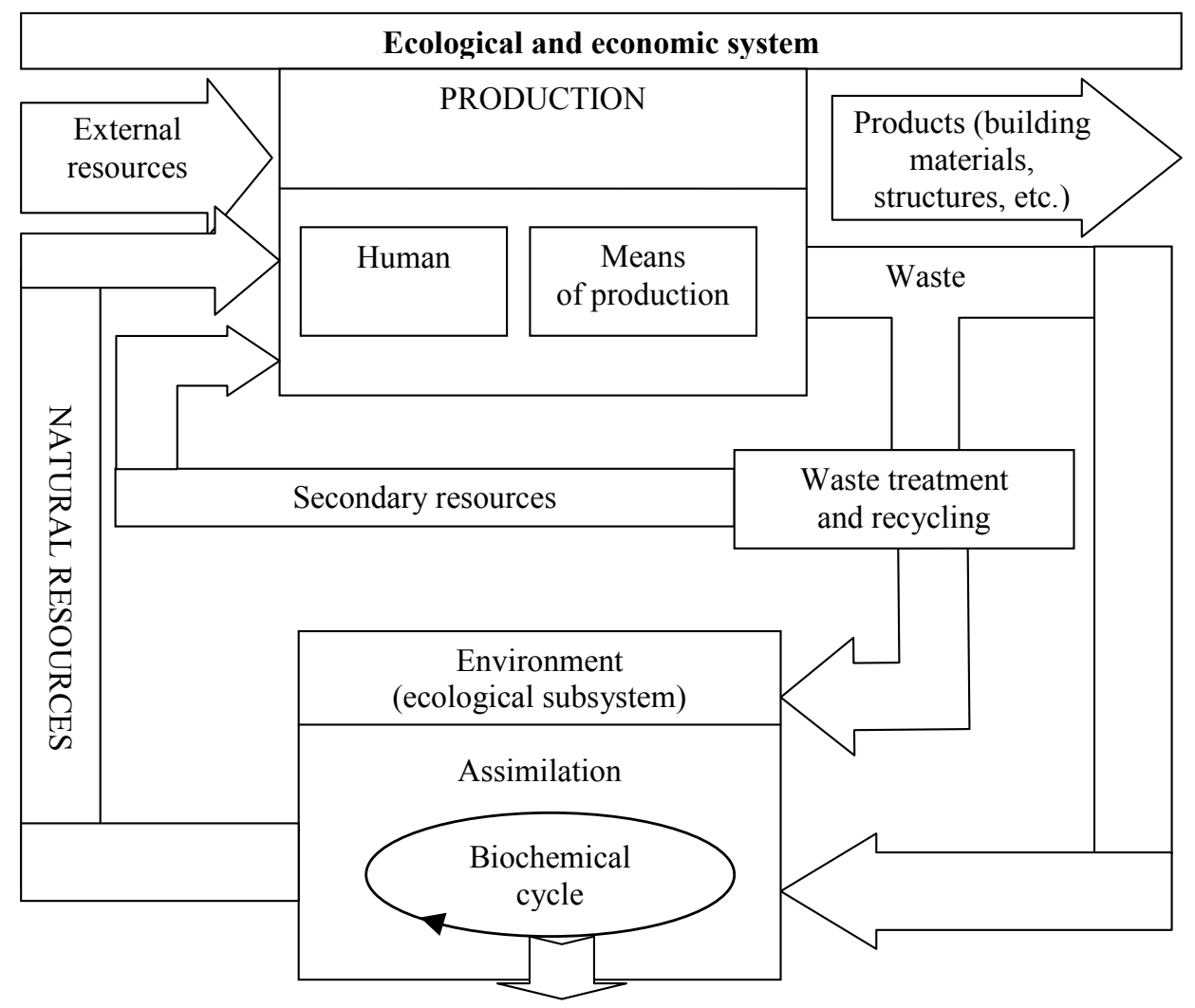

Figure 1. Ecological and economic system 
of resources causes the emergence of a large amount of waste that is harmful to the environment. There is a need to include environmental factors in the system of modern production. The solution of this task is achievable on the basis of the concept of ecologically sustainable development. It provides an opportunity to overcome the ecological crisis with simultaneous movement along the path of economic development and is directed to implement a system of economic principles aimed at preserving the environment, incorporating environmental factors into the functioning mechanism of the market (Malyshev and Solodkov, 2014).

Many domestic and foreign scientists were engaged in studying the impact of economic activity on the ecological situation in the world: V. Andreitsev, Yu. Arutyunov, T. Dietz, A. Getman, V. Gurman, V. Kiseleva, V. Kirilenko, A. Malovsky, P. Nesterov, S. Pereverzeva, V. Razumovsky, R. Rycroft, J. Regens, G. Serov, K. Smith, M. Sharygina, M. Shulga, S. Voduanitskaya, A. Yablokov, and others. Intensive economic activity at marine exacerbated the problem of the ecology of the World Ocean, which began to be regarded as a global problem.

\section{The economic complex as an important component of the development of the real sector of the economy}

With the growth of the economies of the world's states, the volume of international trade and, as a consequence, the importance of the marine economic complex increases.

The development of the country's marine-economic complex is one of the priorities for the development of the economic potential of the state that has access to the marine. According to modern research, the transport infrastructure occupies a leading role in the system of the world economic complex. Since our planet is surrounded by a $2 / 3$ water shell, which includes the seas and oceans, the main economic resource for economic activities is the marine economic complex.

Particularly relevant for Ukraine as a sea power is the rational economic development of the marine economic complex in terms of both economic growth and rational use of natural resources from an ecological point of view. A positive factor in this sense is the interest of the legislator in the sphere of development of the marine economic complex. Undoubtedly, the positive factor was the adoption of the Sea Doctrine of Ukraine for the period until 2035, approved by the Cabinet of Ministers of Ukraine on October 7, 2009, No. 1307.

At one time, scientists such as O. Kibik, O. Podtserkovnyi, Yu. Drapailo, V. Kotlubai and others made efforts to study the questions of determining the marine economic complex. As well as V. Kovalevsky, Yu. Sednev, S. Savelyev, but not one of the definitions did not take into account the environmental component, as equivalent to economic and legal activities.
The marine economic complex is defined as "the territorial combination of economic entities of the maritime transport industry, subjects of other industries, regardless of ownership, that interact with each other and compete within the same field of activity, in order to meet the needs of the population and social production in maritime transport products and services by means of use of natural, intellectual-professional and man-made means" (Kotlubai, 2014). Other scientists define the marine economic complex as "a complex, multicomponent managed system, which objective functions are to ensure the economy of the countries with natural resources of the seas and oceans, expand the external economic potential that is formed at the level of enterprises, regions, and countries" (Kovalevsky, 1998). However, these definitions do not take into account the ecological orientation of the marine economy, although this orientation should promote the development of partnership and good-neighbourliness with other countries since, unlike the state borders, if desired, the economy of the country can be separated, the ecological state of marine natural resources cannot be objectively limited by any boundaries, since a person cannot influence the laws of the functioning of nature as a single cyclically circulating system.

It seems expedient to define the marine economic complex as a multi-purpose system of economic activity in the sphere of the use of marine natural resources, taking into account the rational and balanced development of the country's economy and the preservation and restoration of the ecological state of the marine environment of the country itself and preventing the deterioration of the ecological state of the natural resources of the neighbouring countries.

\section{3. "Environmental" problems and directions of development of the marine economic complex}

The world approach at the moment is expressed in the fact that environmental safety is the priority of any activity.

However, with the growth of human needs, the emergence of engineering, the extraction of minerals and the imbalance of nature management, the global environmental situation has recently deteriorated significantly. According to world analysts, the coastal objects of seaports cause the greatest harm to the region's ecology $-77 \%$ - are industrial facilities that throw waste into the atmosphere and water resources (Semina, 2006).

Intensive use of watercourses, surface and underground water bodies often leads to depletion of water resources. So, during irrigation about $50-75 \%$ of all water used is lost, industry and municipal services give $10-20 \%$ of irretrievable runoff.

In order to maintain the condition of the water body in accordance with environmental requirements, the 
volume of the maximum permissible irrevocable water withdrawal is established and the requirements for environmental releases (discharge of water from the reservoirs) are established. The main criterion, at the same time, is the provision that in water bodies there should remain such a quantity of water that would ensure not only the ecological well-being of the water body but also the necessary conditions for water use.

One of the priority directions of sustainable development of the Black Sea region of Ukraine is cruise shipping since it has a huge effect on the development of the regional economy. Ukraine has all the opportunities for the development of various types of marine tourism: cruise, yacht, beach, and others (Golubkova, 2017, p. 205). The development of this sector will provide additional revenues to budgets of all levels, first of all, the local budget, creation of new jobs in the spheres involved in servicing cruise passengers, stimulation of the development of related industries, including shipbuilding and ship repair (Golubkova, 2018). However, in recent years, the number of cruise ships entering the Black Sea has significantly decreased (Table 1).

Table 1

\section{Analysis of ship calls of passenger liners} to the port of Odesa

\begin{tabular}{|c|c|}
\hline Year & Quantity of ships \\
\hline 2013 & 106 \\
\hline 2014 & 32 (applications -159$)$ \\
\hline 2015 & 13 \\
\hline 2016 & 5 (applications -36$)$ \\
\hline 2017 & $1+12$ (applications -17$)$ \\
\hline 2018 & 17 applications (forecast) \\
\hline
\end{tabular}

Source: (Golubkova, 2018)

The reasons for such a sharp decline were events in the east of Ukraine, high port charges, unprofitable cruises in the Black Sea region, insufficient volumes of investment in modernization of the port cruise and tourist infrastructure and fleet. However, this area has opportunities for redirecting the economic activities of cruise operators in the development of domestic routes (sea, river, river-sea).

However, the problem of pollution of the sea (coastal zone) from ships is topical. According to forecasts, the volume of international traffic will grow by an average of $4.5 \%$ per year, which, accordingly, entails the number of emergency events with tankers, and the risk of pollution of the marine environment by oil and oil products (Gutsulyak, 2000). Therefore, a comprehensive, systematic approach is required in the cooperation of states in the field of protection of the marine environment from pollution from ships and the study of such cooperation in interaction.

According to the International Maritime Organization (IMO) of the United Nations, the ships of the world fleet annually transport 10 billion tons of ballast water, which carries 7-10 thousand species of viruses, bacteria, invertebrates, eggs and larvae of fish, other components of plankton that potentially become harmful in the ports of call. For example, it is proved that the cholera pandemic (1961-91), on the island of Sulawesi, epidemics of cholera on the coast of Peru are associated with shipping. In 1991-92 years in the USA, the causative agent of cholera in the water ballast of ships was found. When analysing the ballast water samples from ships arriving from China, India, Japan, Vietnam and North Africa, causative agents of intestinal infections and helminth eggs were detected (Korotkiy, 2002).

In 2004, IMO adopted the International Convention on the Control and Management of Ships' Ballast Water and Sediment (Ballast Water Management Convention, 2004). This issue is also regulated internationally by the United Nations Convention on the Law of the Sea (1982), the International Convention for the Prevention of Pollution from Ships (1973), the Convention on the Prevention of Marine Pollution from Dumping of Wastes and Other Matter (1972), the Convention on Intervention on the High Seas in Cases of Oil Pollution Casualties (1969), the Convention on Civil Liability for Oil Pollution Damage (1969).

Cities in the coastal zone are often at the same time the centres of shipping companies, ocean fisheries (Odesa), ports and resorts (Mykolaiv), coordinate research and training activities for the marine economy, they accommodate sea transport, fishing industry (coastal and sea fishing), and resort economy. For example, in the city of Odesa and the nearest suburban zone, which have unsurpassed resort potential, there are chemical facilities, an oil terminal for reloading and processing crude oil, a reloading cargo centre operates in the port in the centre of Odesa, oil and gas exploration and production on the Black shelf and the Sea of Azov. All this contributes to the development of economic potential, but the environment suffers from this.

In modern conditions, the development of cities is accompanied by an increase in the volume and pace of construction, the complexity of the transport complex, the removal of industrial enterprises to the outskirts, the desire to smooth differences in the quality of the urban environment of new buildings and the centre, which implies the specialization of development projects. Atmospheric air pollution is the most serious environmental problem of the modern city; it causes significant damage to the health of citizens, to the material and technical facilities located in the city (buildings, facilities, facilities, industrial and transport equipment, communications, industrial products, raw materials and semi-finished products) and green plantations.

As a result of the work of industrial enterprises in the coastal zone of the sea, atmospheric air pollution 
is observed. Excess of standards of air pollution in Ukraine is observed in such cities as Odesa, Mykolaiv, Chornomorsk, Yuzhne. The main substances that determine the high level of pollution in Odesa are: formaldehyde, benzo(a)pyrene, phenol, carbon fluoride, nitrogen dioxide, dust (Lysenko, 2017).

Therefore, Guidelines for Integrated Coastal Zone Management, in conjunction with the Directive of the European Parliament and Commission 2014/89/EU of July 23, 2014, approving the standards of marine spatial planning, which define the principles of rational coastal and marine planning and management, become especially topical. The purpose of such legal regulation is to promote the rational and sustainable use of seas and coastal resources, balance the socio-economic and environmental interests, as well as improve the quality of decisions.

"The maritime policy and territorial structure of the EU are very closely related, and this can be seen in the fact that marine politicians are beginning to shift into the sphere of state internal affairs, which requires a rethinking of how power is distributed among territorial bodies that have the legal authority to be involved in the formation of these policies and some tools such as marine spatial planning" (J. L. Suárez de Vivero, J. R. Mateos and D. F. Corral, 2009).

A clear implementation of the EU Urban Wastewater Treatment Directive, the Agricultural Nitrate Directive, the Directive on the creation of a basis for the planning of maritime areas, etc. It should be noted that the implementation of the Association Agreement with the EU, in particular, the Directive No. 2011/92 on Impact Assessment of certain public and private projects on the environment, as well as the relevant provisions of Directive No. 2003/4 on public access to environmental information, the Convention on Environmental Impact Assessment and the Convention on Access to Information, Public Participation in Decisionmaking and Access to Justice in Environmental Matters (Aarhus Convention), Ukraine adopted the Law "On Environmental Impact Assessment” on May 23, 2017.

Unfortunately, at present, the obligation to conduct an environmental impact assessment of the project has not yet been adequately implemented. According to the Ministry of Ecology and Natural Resources of Ukraine, as of March 2018, there are 200 procedures initiated, and by the end of the year, it is expected that this amount will reach 1,000. But compared to our neighbours, in Poland, there were approximately 1500 applications for this procedure in 2017 (Ukrinform.ua, 2018). At the same time, the lack of this Law is that economic activity, which is already underway, does not require an environmental impact assessment, which may harm it.

The most painful environmental factors affect the economy in case of catastrophes. On the territory of Ukraine, an environmental disaster was the event in the Kerch Strait of the Black Sea, when due to a storm on November 10-11, 2007, 15 vessels were damaged in the strait. Catastrophic for the ecology of the sea and coastal area was the pouring into the sea of about 1.2 thousand tons of fuel oil from the Russian tanker "Volgoneft-139", which broke in half (Medvjedjeva and Andrusevych, 2015). In addition, because of the storm, Vilnohirsk, Khach-Izmail, Nakhchivan, and Kovel, which transported about 2,000 tons of sulphur, also sank. During several days following the accident, there was a massive loss of birds and fish in the Kerch Strait. Already five days after the shipwreck, the AzovBlack Sea territorial department of the Federal Agency for Fisheries of the Russian Federation estimated the total ecological damage in more than 10 billion US dollars. However, the amount of insurance of the owner of "Volgoneft-139" to the third parties was $\$ 5$ million, which is clearly not enough to compensate (Medvjedjeva and Andrusevych, 2015). The settlement of the ecological catastrophe and the search for a compromise are still going on.

\section{Conclusions and suggestions}

In the economic and environmental assessment, it is necessary to distinguish two aspects related primarily to the intensity of economic activity of the objects of the marine complex, as well as to its direct and indirect influence on the coastal zone and marine areas (Lysenko, 2017). The main task of researchers in this field is the formation of a balanced interaction of the environment with the economy through the introduction of environmentally friendly technologies in production. The essence of ecologization is the preservation of the balance of production, the introduction of innovative technologies, the restructuring of the production and consumption, the rationalization of nature management, processing and utilization of waste, implemented at macro and microeconomic levels (Melnik, 2001).

To fulfil this task, it is necessary to develop and take into account the following environmental and economic aspects:

1. Study of the impact of the economic project, plan or program of the marine complex on the ecological situation in the region, starting with the development and construction (implementation) phase.

When studying the correlation of economic and ecological expediency of using one or another component of the ecosystem, the main result should be the allocation of the greatest economic effect with minimal environmental losses.

\section{Ensuring standards.}

The project documentation should include a comprehensive assessment of the envisaged technical solutions for the rational use of natural resources and measures to prevent the negative impact of construction (including the processes of production, installation, commissioning, operation, storage, transportation, sale, 
and disposal) and operation of the marine complex facility on the environment sanitary-epidemiological, ecological requirements, fire, industrial, nuclear, radiation and continued safety). It is also important to strengthen the responsibility of bodies and persons carrying out expert environmental activities.

3. Tightening control over the extraction of natural resources, the impact of construction and operation of the facility on the environment.

It is necessary to understand that the resources of the planet are not unlimited, so it is necessary to seek an economic and ecological balance - both for the extraction and processing of useful resources in order to save them. The economic activity of a person in any territory should be based on the use of local renewable natural resources, but not exceed their ability to regenerate.

4. Development of environmental sections for the feasibility study of urban development projects in the coastal zone.

"Involving terrestrial designers and decision support methods that they use offers special advantages ... Marine spatial planning should be applied across the jurisdiction of individual countries but with varying degrees of detail" (P.M. Gilliland and D. Laffoley, 2008).

When planning the construction of facilities within the city in the coastal zone, the following priorities should be observed: strict adherence to the technological sequence of construction; reduction of construction time; complex use of the underground space of the city.

When planning the construction of environmentally hazardous enterprises and organizations in the coastal zone, the following priorities should be observed: maximum reform and (or) elimination of environmentally hazardous enterprises and organizations; the maximum delivery of these facilities beyond the city limits, taking into account the opportunities for people's work and economic activities.

Summarizing the above, it should be noted that for the development of the state's marine complex, it is necessary, first of all, to assess the impact of the development of this sector of the economy on the environment in the region and then develop that direction of the economy that is the least harmful to the environment in the region and only in view of this can bring large economic benefits.

\section{References:}

Akimova, T. A., Khaskin, V. V. (2001). Ekologiya. Chelovek - Ekonomika - Biota - Sreda [Ecology. Human Economy - Biota - Environment] Moskva: YUNITI-DANA. (in Russian)

Syromyatnikova, O. P. (2011). Sovershenstvovanie mekhanizma regionalnogo upravleniya lokalnymi ekologoekonomicheskimi sistemami [Development of the mechanism of regional managem ent of local ecological and economic systems]. Ekonomika i ekologicheskiy menedzhment, 2, 244-253.

Malyshev, A. A., Solodkov, N. N. (2014). Faktory, vliyayushchie na ustoychivost ekologo-ekonomicheskoy sistemy [Factors affecting the sustainability of the ecological and economic system] Niva Povolzhya, 30, 129-135.

Kibik, O. M., Podtserkovnyi, O. P., Drapailo, Yu. Z., Kotlubai, V. O. (2014). Derzhavna pidtrymka rozvytku moreghospodarsjkogho kompleksu Ukrajiny (orghanizacijni ta pravovi aspekty) [State support for the development of the marine-economic complex of Ukraine (organizational and legal aspects)] Kherson: FOP Ghrinj D. S. (in Ukrainian)

Kovalevsjkyj, V. V., Mykhajljuk, O. L., Semenov, V. F. (1998). Rozmishhennja produktyvnykh syl [Placement of productive forces)] Kyjiv: Tovarystvo «Znannja»; KOO. (in Ukrainian)

Semina, N. V. (2006). Ekologo-ekonomicheskie aspekty sistemy menedzhmenta okruzhayushchey sredy gosudarstvennogo predpriyatiya «Morskoy torgovyy port Yuzhnyy» [Environmental and economic aspects of the environmental management system of the state enterprise "Sea Commercial Port Yuzhny"]. Proceedings of the Razvitie predpriyatiy morekhozyaystvennogo i neftegazovogo kompleksov: V Mezhdunarodnaya nauchno-prakticheskaya konferentsiya (Ukkaine, Odessa-Yuzhnyy, 2006), Odessa-Yuzhnyy: Druk, pp. 44-47.

Gholubkova, I. A. (2017). Osnovni tendenciji funkcionuvannja morsjkogho turyzmu v Ukrajini [The main tendencies of the functioning of the nautucal tourism in Ukraine]. Proceedings of the Morsjke pravo ta menedzhment: evoljucija ta suchasni vyklyky: XI Mizhnarodna naukovo-praktychna konferencija NU «OMA» Ukraine, Odessa, April 6-7, 2017) (eds. Mijusov M. V., Gholikov V. A., Shemjakin O. M. etc.), Odessa: NU «OMA», pp. $204-207$.

Gholubkova, I. A. (2018). Suchasnyj stan reghionaljnogho krujiznogho sudnoplavstva [The current state of regional cruise shipping]. Proceedings of the Morsjke pravo ta menedzhment: evoljucija ta suchasni vyklyky: XII Mizhnarodna naukovo-praktychna konferencija NU «OMA» Ukraine, Odessa, March 29-30, 2018) (eds. Mijusov M. V., Gholikov V. A., Shemjakin O. M. etc.), Odessa: NU «OMA», pp. 126-129.

Gutsulyak, V. N. (2000). Morskoe pravo [Maritime Law] Moskva: RosKonsult. (in Russian)

Korotkiy, T. R. (2002). Mezhdunarodno-pravovaya okhrana morskoy sredy ot zagryazneniya s sudov [International legal protection of the marine environment from ships pollution] Odessa : Latstar. (in Russian)

Lysenko, N. S. (2017). Ekonomiko-ekonologicheskie aspekty razvitiya morekhozyaystvennogo kompleksa [Economic and ecologic aspects of the development of the marine economic complex]. Proceedings of the Morsjke pravo ta menedzhment: evoljucija ta suchasni vyklyky: XI Mizhnarodna naukovo-praktychna konferencija NU «OMA» Ukraine, Odessa, April 6-7, 2017) (eds. Mijusov, M. V., Gholikov, V. A., Shemjakin, O. M. etc.), Odessa: $\mathrm{NU} \ll \mathrm{OMA} »$, pp. 215-219. 
Juan L. Suárez de Vivero, Juan C. Rodriguez Mateos, David Florido del Corral (2009). Geopolitical factors of maritime policies and marine spatial planning: State, regions, and geographical planning scope. Marine Policy, 33, 624-634.

Ukrinform.ua (2018). Dva misjaci novomu Zakonu Ukrajiny «Pro ocinku vplyvu na dovkillja». Shho zminylosja pislja skasuvannja ekologhichnoji ekspertyzy? [Two months of the new Law of Ukraine "On the assessment of the environmental impact". What has changed since the environmental expertise was abolished?] (unpublished). Retrieved from: https://www.ukrinform.ua/rubric-presshall/2419890-zakon-ukraini-pro-ocinku-vplivu-nadovkilla-so-zminilosa-pisla-skasuvanna-ekologicnoi-ekspertizi.html (accessed 10 August 2018)

Medvjedjeva, M. O., Andrusevych, A. O. (2015). Osoblyvosti stvorennja i zastosuvannja mizhnarodno-pravovykh zvychajevykh ta doghovirnykh norm u ghaluzi okhorony navkolyshnjogho seredovyshha [The specialties of the creation and application of international legal customary and treaty rules in the field of environmental protection]. The Herald of the Kyiv, no. 6, pp. 66-69.

Melnik, L. G. (2001). Ekologicheskaya ekonomika [Ecological economy] Sumy: «Universitetskaya kniga». (in Russian)

Paul M. Gilliland, Dan Laffoley (2008). Key elements and steps in the process of developing ecosystem-based marine spatial planning. Marine Policy, 32, 787-796. 